\title{
МЕДІАТЕХНОЛОГІї
}

\author{
Visn. Lviv. Univ., Ser. Zhurn. 2019: 46; 244-251 • DOI: http://dx.doi.org/10.30970/vjo.2019.46.10060
}

УДК 316.33.42/77(477)

\section{НОВІ ФОРМИ ДЕМОКРАТІЇ, ПОЛІТИЧНА КОМУНІКАЦІЯ Й ГРОМАДЯНСЬКЕ СУСПІЛЬСТВО}

\author{
Олена Гриценко \\ Дипломатична академія Украӥни імені Геннадія Удовенка при МЗС Украӥни, \\ вул. Велика Житомирська, 2, 01001, Київ, Украӥна \\ e-mail: o.m.h@i.ua \\ https://orcid.org/0000-0001-8339-9165
}

Свобода обміну інформацією та інформаційна відкритість є однією з фундаментальних основ громадянського суспільства. Саме сучасні інформаційно-комунікаційні технології відкривають нові можливості для вільного поширення інформації та масового інформаційного обміну, наслідком чого може стати формування принципово нового типу демократичного суспільства.

Ця стаття $є$ спробою простежити, як співвідносяться постіндустріальні соціальноекономічні трансформації й громадянське суспільство; як становлення постіндустріального суспільства впливає на процеси політичної комунікації й на виникнення нових форм політичного устрою; взаємозалежність зростання (завдячуючи інформаційним технологіям) інформаційної відкритості, політичної комунікації й громадянського суспільства.

Ключові слова: постіндустріальне інформаційне суспільство, громадянське суспільство, політична комунікація, «четверта влада», інформаційна відкритість.

Актуальність та новизна проблеми. Одним з найважливіших наслідків становлення постіндустріальної цивілізації стала демасифікація виробництва й споживання, які набули індивідуалізованого характеру. Тому сьогодні ідеали суспільства масового споживання з їхнім категоричним імперативом «необхідно бути такими, як усі» втрачає свою актуальність. Крім того, складна діалектика влади й особистої свободи в постіндустріальному суспільстві визначає специфіку суспільної свідомості, створюючи умови, коли більшість людей вже не згодна на роль «гвинтиків» у соціальному механізмі, що слухняно виконують вказівки влади. Так починається активізація політичної свідомості й політичної культури, а політична комунікація перестає бути традиційно спрямованою «зверху», зважаючи на активізацію альтернативної політичної комунікації «знизу». Ці соціально-політичні процеси у постіндустріальному суспільстві пов'язані вже не стільки з проблемою демократії (це поняття стало політичним кліше, що значною мірою втратило свій зміст), скільки 3 ідеєю громадянського суспільства.

(C) Гриценко О., 2019 
Отже, що являє собою сучасна демократія, які її основи й чим вони відрізняються від античних уявлень про демократію, від змісту цього поняття в середньовічні часи або в епоху індустріального капіталізму? Ці питання набувають особливої актуальності у зв'язку з тим, що з кінцем індустріальної епохи усталені основи класичної демократії залишися у минулому, а в суспільстві, де основним економічним ресурсом стають знання та інформація, виникають нові форми політичної організації, які дослідник В. Іноземцев вважає подібними до аристократичного устрою. Хоча тенденція створення «нової аристократії» постіндустріального суспільства (тих «глобальних багатих», яких дослідник 3. Бауман протиставляє «локальним бідним») справді існує, очевидно, домінуючим напрямком змін у політичному устрої $\epsilon$ все ж таки ідея громадянського суспільства, яка передбачає активізацію політичної культури членів суспільства й зростання ролі альтернативної політичної комунікації «знизу».

Аналіз досліджень із проблематики роботи. На думку відомого англійського дослідника Л. Зідентопа, в основу європейської демократії було покладено християнське вчення про духовну рівність людей перед Богом та вищий за матеріальні інтереси моральний закон - ідею, невідому античній цивілізації. Залежність європейської демократії від цих світоглядних позицій можна бачити в історії середньовічних міст, які спочатку об'єднувалися навколо церковної влади; лише пізніше виникли демократичні комуни європейського середньовіччя.

Під впливом ідей духовної рівності й морального закону в Європі сформувалися уявлення про громадянство й громадянське суспільство. У порівнянні з античною моделлю демократії громадянське суспільство $€$ повною протилежністю - в його основі пріоритет приватного й особистого над суспільним, недоторканість приватного життя, а в кінцевому рахунку - загальна рівність всіх членів суспільства перед законом.

Концепція громадянського суспільства має свої витоки у деяких ідеях Г. Гроція, Т. Гоббса, Дж. Локка та протестантизму. Вперше вона була достатньо чітко висловлена в 1767 р. у книзі Адама Фергюсона «Нариси з історії громадянського суспільства». Подальший її розвиток можна бачити у працях Ж.-Ж. Руссо. Через французьких енциклопедистів та діячів Французької революції концепція громадянського суспільства, на той час ще абстрактна, мала вплив на створення основ американської демократії. Серед європейських мислителів XIX ст. до ідеї громадянського суспільства зверталися Г. Гегель, який чітко розмежував державу й громадянське суспільство та К. Маркс - висловив важливу думку про вторинність держави відносно громадянського суспільства. Таке розмежування дозволяє усвідомлювати взаємовідносини держави й громадянського суспільства, розглядаючи їх як рівноцінних партнерів у політичній комунікації.

Практичні спроби реалізації ідеї громадянського суспільства були здійснені у XVII-XVIII ст. в Англії - країні, яку навряд чи можна назвати більш демократичною, ніж інші країни Європи того часу. Проте саме в Англії рівність членів суспільства перед законом стала важливішою, ніж демократична ідея можливості всіх брати участь у прийнятті законів.

Розкриття проблематики. Особливого значення концепція громадянського суспільства набула в останнє десятиріччя XX ст., коли вона стала реально втілюватися у життя у США та країнах СС. Це було зумовлено становленням постіндустрі- 
ального суспільства та інформаційною революцією, яка забезпечила принципово новий рівень інформаційної відкритості діяльності державно-владних інституцій.

Передумови практичної реалізації ідеї громадянського суспільства в країнах ЄС й США суттєво відрізнялися. 3 самого початку історії американської держави колоністам було властиве сильно виявлене почуття індивідуалізму та переважно однакові ціннісні орієнтації, а також мовна єдність. В Європі становище було іншим там завжди були характерними патерналістські відношення держави й громадян, а індивідуалістичні цінності були виявлені менше, ніж у США. Тому моделі державного устрою США та країн СС при, здавалося б, їхній подібності суттєво відрізняються - у політичній системі США ідеї ліберальної демократії й федералізму втілені значно більше. В цілому ж, сутність ідеї громадянського суспільства полягає у розмежуванні державних і громадських інституцій, завдяки чому виникає можливість їхніх партнерських відносин на відміну від традиційної зверхньої ролі держави.

Держава (принаймні, у західноєвропейському розумінні) має надавати всім громадянам право рівності перед законом, більш того - єдиний соціальний статус. Тому повноцінна держава сумісна не з кожним соціальним ладом і передбачає індивідуалістичну модель суспільства, оскільки рівність у статусі, яку надає громадянам держава, створює основу для відокремлення суспільного життя від приватного. Так виникає первинна соціальна роль, «метароль» громадянина в соціумі - та роль, яка без повноцінної держави взагалі не може існуватих [1: 102, 110-115]. Деякі дослідники вважають, що громадянське суспільство має неполітичну природу, але в такому разі політичні партії виявляються за межами громадянського суспільства, з чим не можна погодитися, оскільки саме вони $є$ найважливішими політичними інститутами громадянського суспільства, пов'язуючи його з державно-владними структурами. Саме розмежування права й закону дає можливість протиставляти право сваволі пануючих у суспільстві кланових угруповань (як відомо, ця сваволя нерідко набуває рангу закону). Саме тому громадянське суспільство неможливе без правової держави, а дійсно правова держава неодмінно передбачає існування громадянського суспільства.

В Україні, за відомих історичних обставин, суспільна думка була зорієнтована у 1990-і pp. не на громадянський, а перш за все на національно-визвольний аспект державотворення, наслідком чого стала недостатня розвиненість концепції взаємовідносин між державою та громадянським суспільством у порівнянні з аналогічними концепціями в Німеччині, Англії та Франції. Після проголошення незалежності в Україні почався процес формування самодіяльних об’єднань громадян, а провідну роль у становленні громадянського суспільства почав відігравати розвиток системи місцевого самоврядування. Проте в українських умовах це ускладнено тим, що одночасно відбуваються три взаємопов'язані, але у той же час окремі процеси: національне відродження, побудова правової держави й формування громадянського суспільства.

Хоча, здавалося б, очевидною є думка про доцільність запозичення досвіду становлення громадянського суспільства в західних країнах, проблема полягає в тому, що навряд чи можливий прямий експорт західної моделі демократичного устрою й громадянського суспільства в інші регіони світу, де існують інші культурні традиції, зокрема в Східну Європу. В тих суспільствах, де первинна соціальна «метароль» індивіда по відношенню до держави не сформувалася протягом історії розвитку їхнього політичного устрою, основним суб’єктом соціально-економічного життя стає 
вже не індивід, як в Західній Європі та США, а сім’я, клан або інші соціальні групи та спільноти.

Щодо взаємин влади й суспільства, то сьогодні ключовою проблемою в цих взаєминах $є$ вплив мас-медіа на громадську думку. Тут треба зазначити, що відома метафора «мас-медіа це четвертверта влада» $є$ некоректною, оскільки на початкових стадіях становлення громадянського суспільства «четвертною владою» реально може бути лише громадська думка (на формування якої активно справді впливають мас-медіа). А мас-медіа, у тому числі традиційні друковані ЗМI, повинні бути засобами виявлення громадської думки. На розв’язанні зазначених проблем, що істотно впливають на весь процес соціокультурних трансформацій будь-якого суспільства, має бути спрямована вся державна інформаційна політика.

Крім того, хоча у пострадянських країнах основною метою реформ було проголошено демократію, як зовнішню форму управління, досвід ще 1990-х рр. свідчить, що демократія може мати різні форми, які не завжди $є$ конструктивними. Демократія може бути розвинутою більшою чи меншою мірою; вона може стримуватися аристократичними чи іншими (наприклад, номенклатурними) пережитками; нарешті, вона може бути популістською та саморуйнівною. Проте лише громадянське суспільство 3 його рівністю громадян перед законом може надати демократії цивілізовані форми [2]. Очевидно, метою реформ повинна бути не просто демократія, а створення громадянського суспільства й такої держави, у відношенню до якої всі громадяни були 6 рівними в своїй соціальній метаролі індивіда. Лише в громадянському суспільстві мас-медіа перетворюються з інструменту державної політики на засіб контролю 3 боку громадянського суспільства над державою та, внаслідок цього, дійсно стають «четвертою владою».

3 концепцією громадянського суспільства, в основу якої покладено ідею соціально-політичної активності окремих громадян та громадських організацій (перш за все на локальному й регіональному рівнях) пов'язані такі поняття як «культура громадянськості» й «політична культура» [3].

На формування культури громадянськості впливає перш за все громадська думка, яка не тільки є одним 3 найважливіших чинників політичної комунікації в суспільстві, а й способом виявлення масової свідомості, що передає ставлення членів суспільства до значущих подій та фактів. Громадська думка формується стихійно, у процесі спілкування, та цілеспрямовано за допомогою мас-медіа; вона формується в суспільстві в цілому та в окремих спільнотах (соціальних, регіональних, професійних, політичних, культурних тощо).

Однак, добре відомо, що українські мас-медіа мають значний досвід виконання політичних замовлень та маніпулювання громадською думкою. Проблема залежності політичної орієнтації багатьох медіа від їхніх фінансових зв'язків з клановими угрупуваннями неодноразово порушувалася самими мас-медіа, що суттєво зменшило довіру аудиторії до значної кількості видань як до незалежних спостерігачів. Внаслідок цього в Україні стали виявлятися певні труднощі у перетворенні мас-медіа на новий соціально-політичний інститут, який повинен не тільки інформувати читацьку аудиторію, але й консолідувати суспільство.

Сьогодні економічна самостійність мас-медіа справді $є$ досить умовною, а друкованим виданням внаслідок різкого скорочення обсягу передплати важко забезпечити власне виживання без сторонньої фінансової підтримки. Тому характерною 
рисою, зокрема, українських політичних медіа є значне збільшення ролі рекламних технологій, що пояснюється не тільки комерціалізацією мас-медіа, а й зміною функцій реклами та набуття нею нового значення, зокрема у контексті PR-технологій та створення іміджу політичних діячів. Це той політичний адвертисмент, який структурує інформаційний медіа-простір, підпорядковуючи собі партійну пресу, теле- й радіопередачі (особливо в час передвиборчої кампанії). Звісно, завдяки інформаційно-комунікативній функції у процесах демократичних трансформацій, мас-медіа стають одним 3 найважливіших чинників формування політичної культури, яка визначає зміст і якість соціальних цінностей, традицій та норм, що регулюють політичні відносини у суспільстві. Складність полягає в тому, що мас-медіа є водночас продуктом громадської думки й тією силою, яка цю думку формує.

Комунікативна концепція політичної влади (Х. Аренд, Ю. Габермас) заснована на ідеї, що будь-яка влада прагне домогтися у підлеглих згоди з іiї рішеннями, а кожен член суспільства намагається висловити свої потреби. Політична комунікація полягає у передачі інформації між основними суб’єктами політики - суспільством та інститутами влади, а влада розглядається як опосередкований, ієрархічний механізм спілкування між людьми, де загальний інтерес переважає над частковим. Ю. Габермас уточнював, що влада $€$ механізмом опосередкування суперечностей, які виникають між публічною й приватною сферами життя. Тому й політична комунікація не однакова за умов різних політичних режимів. Якщо в демократичній державі вона плюралістична, то в тоталітарній чи авторитарній державі вона монополізована.

Сьогодні в Україні та інших пострадянських суспільствах політична комунікація $є$ відносно вільною. В умовах неефективного управління з боку влади сама влада стає нелегітимною для певної частини суспільства. Внаслідок цього нелегітимною починає сприйматися й політична комунікація, якїй перестають довіряти, а це в свою чергу не сприяє зміцненню довіри між владою та суспільством.

Західна політологічна наука визначає сутність політичної комунікації як сукуnність комунікаційних процесів між політичною системою та суспільством 3 метою формування громадської думки, яка впливає на прийняття політичних рішень. На наш погляд, більш повним було б таке визначення: політичною комунікацією є діалог між владою та суспільством, який здійснюється за допомогою мас-медіа й має на меті зростання інтеграції суспільства. У процесі політичної комунікації мас-медіа задають певні стереотипи сприйняття соціальних процесів та норми політичного діалогу влади й суспільства, й завдяки цьому об’єднують аудиторію споживачів політичної інформації, перетворюючи її з простої сукупності членів суспільства, іноді віддалених один від одного фізично й географічно, у цілісну спільність - громаду.

Простежуючи сучасні тенденції у розвитку політичної комунікації, необхідно зазначити, що сьогодні, як в Україні, так і в країнах Заходу можна спостерігати суттєве зниження підтримки політичних установ і політичних діячів з боку суспільства. Відсоток осіб, що беруть участь у голосуванні, постійно зменшується. Це явище пов'язано з тим, що існують два види підтримки тих чи інших політичних сил - специфічна й дифузійна. У той час як перший вид підтримки пов'язаний з довірою до конкретних політичних заходів чи лідерів, другий передбачає підтримку загальних демократичних принципів. Тенденція до соціально-політичної пасивності зумовлена зниженням дифузійної підтримки, наслідком чого є також і зниження специфічної підтримки окремих політиків. Поширення негативного ставлення до 
політики пояснювалося й тим, у який спосіб процеси політичної комунікації знаходять своє висвітлення в мас-медіа й перш за все у телевізійних програмах, в яких все більше місце почали займати матеріали рекламного та розважального спрямування.

Таким чином, інтерес до традииійної політичної комунікації «зверху» справді знижується. Проте, разом з цим громадяни різних країн виявляють все більшу зацікавленість у конкретних способах розв'язання тих чи інших проблем, актуальних для їхнього регіону.

В американській політології існує вдале поняття grassroots democracy, що можна приблизно перекласти, як «низова демократія», або демократія на повсякденному рівні «простих людей». Типовим прикладом такої grassroots democracy 3 життя нашого суспільства є створення мешканцями багатоквартирних будинків добровільних об'єднань власників квартир, які відмовляються від традиційної для нашого суспільства пасивної позиції й роблять крок до самоорганізації, виявляючи таким чином соціальну активність «знизу» для вирішення конкретних локальних проблем. Добре відомо, що у США та країнах Західної Європи подібні форми grassroots democracy поширені набагато більше, а соціальна активність громадян у цілому $є$ значно вищою. Таку тенденцію називають, як правило, нетрадиційною (альтернативною) формою політичної комунікації, пов'язуючи їі з концепцією громадянського суспільства.

Кажучи про вплив мас-медіа на формування масової свідомості за допомогою політичної комунікації, не можна не згадати про проблему маніпулювання поняттям «демократія» з боку тоталітаризму нового, більш витонченого типу - інформаційного тоталітаризму, який для своєї легітимації та самозбереження використовує популярний (але й стереотипний) образ демократичного суспільства. Такий тоталітаризм призводить до стереотипізації масової свідомості та відсутності в носія такої свідомості власної точки зору стосовно політичних подій, не кажучи вже про здатність свідомо й компетентно брати участь у прийнятті політичних рішень. Внаслідок послідовної й цілеспрямованої маніпуляції свідомістю за допомогою мас-медіа створюється видимість демократії, коли громадяни повинні формально приймати політичні рішення (насамперед це стосується передвиборчої кампанії).

Саме тому можливість взаємодії влади з громадськістю як з єдиним цілим сьогодні часто утруднена; значення політичної комунікації в її традиційних формах зменшується, а можливість прийняття важливих політичних рішень внаслідок діалогу між владою й суспільством $є$ дуже сумнівною. 3 огляду на це доцільно розрізняти два види політичної комунікації - иілеспрямовану й нецілеспрямовану. Цілеспрямованою політичною комунікацією $є$ свідомі дії політичних партій та лідерів, що мають на меті одержання підтримки електорату. Нецілеспрямована політична комунікація здійснюється завдяки активності журналістів, мас-медіа та громадських організацій - саме в цій активності втілюються ідеї свободи слова та вільних мас-медіа, які критично оцінюють позицію влади та її дії. Виникає ситуація, в якій медійна галузь, пропонуючи критичне ставлення до політичних подій та особистісних якостей політиків, фактично послаблює роль традищійної політичної комунікації, збільшуючи значення альтернативної політичної комунікації у суспільстві. Влада, в свою чергу, прагне зберігати контроль за процесами альтернативної політичної комунікації, використовуючи для цього всі засоби, спрямовані на одержання підтримки з боку громадської думки (насамперед це стосується політичної рекла- 
ми). До такої спрямованої політичної комунікації залучається все більша кількість кваліфікованих професіоналів, які використовують такі поширені прийоми сучасної журналістики, як короткостроковість інформації, негативізм та персоналізацію.

Висновки. Специфічний характер політичної комунікації породжує високий рівень очікувань з боку суспільства, оскільки імідж державних діячів та політичних лідерів створюється таким чином, що ці політики сприймаються масовою свідомістю як кваліфіковані спеціалісти, здатні швидко розв’язати будь-які проблеми. Проте досить часто ці очікування не виправдовуються, а наслідком цього стає зростання відчуженості все більшої кількості громадян від традиційної політичної комунікації. Втрата політичною системою дифузійної підтримки суспільства призводить до того, що влада прагне використати технології та методи мас-медіа з метою зберегти належний рівень цілеспрямованої (традиційної) політичної комунікації, «керованої зверху» [4: 34-41].

3 причини послаблення впливу традиційної політичної комунікації, керованої державою, особливого значення у наш час набуває властива громадянському суспільству ідея розвитку громадського самоуправління та створення нового, альтернативного потоку політичної комунікації «знизу», ініційованого та підтримуваного активністю окремих громадян та громадських організацій. В сучасних умовах кризи традиційних форм політичної комунікації саме така альтернативна форма комунікації дійсно-може сприяти інтеграції нашого суспільства та його включення в процес розбудови глобальної демократії XXI століття.

\section{REFERENCES}

1. Зидентоп Л. Демократия в Европе. М.: Логос, 2001. С. 110-115.

2. Иноземцев В. Л. Демократия перед вызовом истории // Зидентоп Л. Демократия в Европе. М.: Логос, 2001.

3. Миллер Э. Шарлоттский проект. Как помочь гражданам взять демократию в свои руки. М.: Виоланта, 1998.

4. Glotz P. Chancen und Gefahren der Telekratie // Die Neue Gesellschaft. Frankfurter Hefle, 1995. № 1. P. 34-41. 


\title{
NEW FORMS OF DEMOCRACY, POLITICAL COMMUNICATION AND CIVIL SOCIETY
}

\author{
Olena Hrytsenko \\ Hennadii Udovenko Diplomatic Academy Of Ukraine \\ at the Ministry of Foreign Affairs of Ukraine \\ Velyka Zhytomyrs'ka str., 2, 01001, Kyiv, Ukraine \\ e-mail: o.m.h@i.ua \\ https://orcid.org/0000-0001-8339-9165
}

In this article, we will try to trace how postindustrial socio-economic transformations and civil society relate; as the formation of post-industrial society influences the processes of political communication and the emergence of new, alternative forms of political system; as well as the interdependence of growth (due to new information technologies) of information openness, political communication and civil society.

Freedom of information exchange and information openness is one of the fundamental foundations of civil society. It is the modern information and communication technologies (including the Internet and electronic media) that open up new opportunities for the free dissemination of information and mass information exchange, which may result in the formation of a fundamentally new type of democratic society. Therefore, in western countries special attention is paid to the problems of using information resources on the basis of the use of the latest information technologies, communications and telecommunications.

In democratic states, the interaction of power and society, in addition to the main electoral mechanism, is based on public relations and the provision of information services to the population, as well as on the mechanism of legislative lobbying and public expression of public opinion. These mechanisms function in interaction, although they are different in essence, and in practice they are implemented in parallel, using the same methods and tools. In this exchange of information is an very important link in the system of public administration, since the completeness, quality and reliability of information used to make managerial decisions at all levels determine the correctness, efficiency and effectiveness of such decisions.

Key words: postindustrial information society, civil society, political communication, «fourth power», informational transparency. 